\title{
Hydrometeorological observations from the rain-to-snow transition zone: a dataset from the Johnston Draw catchment, Reynolds Creek Experimental Watershed, Idaho, USA
}

Clarissa L. Enslin ${ }^{1}$, Sarah E. Godsey ${ }^{1}$, Danny Marks ${ }^{2}$, Patrick R. Kormos ${ }^{2}$, Mark S. Seyfried ${ }^{2}$, James P. 5 McNamara $^{3}$, Timothy E. Link ${ }^{4}$

${ }^{1}$ Department of Geosciences, Idaho State University, Pocatello, Idaho, USA

${ }^{2}$ USDA Agricultural Research Services, Boise, Idaho, USA

${ }^{3}$ Department of Geosciences, Boise State University, Boise, Idaho, USA

${ }^{4}$ Department of Forest, Rangeland, and Fire Sciences, University of Idaho, Moscow, Idaho, USA 10

Correspondence to: Sarah E. Godsey (godsey@isu.edu) 
Earth Syst. Sci. Data Discuss., doi:10.5194/essd-2016-44, 2016

Manuscript under review for journal Earth Syst. Sci. Data

Published: 13 September 2016

(c) Author(s) 2016. CC-BY 3.0 License.

(c) (i)

Abstract. Detailed hydrometeorological data from the rain-to-snow transition zone in mountain regions are limited. As the climate warms, the transition from rain to snow is moving to higher elevations, and these changes are altering the timing of down slope water delivery. To understand how these changes impact hydrological and biological processes in this climatologically sensitive region, detailed observations from the rain-to-snow transition zone are required. We present a

5 complete hydrometeorological dataset for water years 2004 through 2014 for a watershed that spans the rain-to-snow transition zone (DOI:10.15482/USDA.ADC/1258769). The Johnston Draw watershed (1.8 km2), ranging from 1497 $1869 \mathrm{~m}$ in elevation, is a sub-watershed of the Reynolds Creek Experimental Watershed (RCEW) in southwestern Idaho. The dataset includes continuous hourly hydrometeorological variables across a $372 \mathrm{~m}$ elevation gradient, on north- and south-facing slopes, including air temperature, relative humidity, and snow depth from 11 sites in the watershed. Hourly

10 measurements of shortwave radiation, precipitation, wind speed and direction, and soil moisture and temperature are available at selected stations. The dataset includes hourly stream discharge measured at the watershed outlet. These data provide the scientific community with a unique dataset useful for forcing and validating models and will allow for better representation and understanding of the complex processes that occur in the rain-to-snow transition zone.

15 Keywords. rain-to-snow transition, mixed phase precipitation, watershed hydrology

\section{Introduction}

As the climate warms and many mountain regions shift from snow domination to a mix of rain and snow, we need to understand how these changes will alter hydrologic response. Hydrometeorological conditions in the rain-to-snow transition zone are very dynamic [Marks et al., 2013], and while comprehensive datasets are needed, data availability is limited. We

20 present a detailed, serially complete, hourly hydrometeorological dataset from the rain-to-snow transition zone to improve understanding of these complex regions, and provide guidance to improve water resource management as the climate warms. The rain-to-snow transition zone in mountainous regions is the elevation band where precipitation phase can vary between rain, snow or a mixture of rain and snow during a single storm event [Marks et al., 2013]. In the northwestern U.S., the elevation of the rain-to-snow transition zone currently ranges from $1500-1800 \mathrm{~m}$ [Nayak et al. 2010] and covers $9200 \mathrm{~km}^{2}$

25 [Nolin and Daly, 2006]. The extent and elevation of this zone are changing with climate conditions, and vary with latitude and distance from the ocean. The precipitation regime in the current rain-to-snow transition zone in the northwestern U.S. is expected to shift from transitional to a rain-dominated system as the climate warms and the zone moves up in elevation [Nayak et al., 2010; Klos et al., 2014]. Mountain rain-to-snow transition zones are important to study because they are particularly sensitive to changes in climate [Klos et al., 2014]. Because these areas experience winter temperatures near

30 freezing [Mote, 2003; Kormos et al., 2014], small changes in weather conditions can alter seasonal snow cover, the timing of melt, the delivery of liquid water to soil and streams, and ultimately, the ecosystems they sustain. 
Earth Syst. Sci. Data Discuss., doi:10.5194/essd-2016-44, 2016

Manuscript under review for journal Earth Syst. Sci. Data

Published: 13 September 2016

(c) Author(s) 2016. CC-BY 3.0 License.

(c) (i)

Although the rain-to-snow transition zone is recognized as important on regional and continental scales [e.g. Mote et al., 2005; Klos et al., 2014; Trujillo and Molotch, 2014; Lute et al., 2015], it is surprisingly poorly characterized. Published watershed-scale datasets of precipitation, temperature, humidity, wind, radiation, snow, and resultant streamflow representative of an entire basin spanning the rain-to-snow transition are limited. We conducted a meta-analysis in order to

5 determine published data availability in the rain-to-snow transition zone. We did this by searching the key words: "rain-snow transition data" OR "rain snow zone data" in Web of Science (search date: 4/16/2016). Out of the 79 returns, only 5 publications $(6.3 \%)$ had published freely available hydrometeorological data in the rain-to-snow transition zone. These 5 datasets are from (1) a small catchment in the Dry Creek Experimental Watershed (DCEW) southwestern Idaho, U.S. [Kormos et al., 2014b], (2) various small- to medium-sized watersheds in the contiguous U.S. [Newman et al., 2015], (3) a

10 site in Washington Cascades, U.S. [Wayand et al., 2015], (4) various sub-watersheds from the Reynolds Creek Experimental Watershed (RCEW) southwestern Idaho [Marks et al., 2013], and (5) a site in Davos, Switzerland [WSL Institute for Snow and Avalanche Research SLF, 2015]. The remaining 74 returns either were conducted in watersheds that did not span the rain-to-snow transition, or the data associated with their research were neither published nor easily available for public use. It is possible that additional datasets exist, but were not discovered using the search terms that we applied (e.g., data from a site

15 Col de Porte, France [Morin et al., 2012]), who describe a dataset, but did not publish it. Although data presented by Morin et al. [2012], Wayand et al. [2015], and WSL Institute for Snow and Avalanche Research SLF [2015] are useful, our dataset is unique because it includes basin-wide measurements and stream discharge, which permit hydrologic modeling and a mass balance approach.

20 In this paper, we present a comprehensive hydrometeorological dataset for 11 water years (WY) from WY 2004 - 2014 for the Johnston Draw (JD) watershed that spans the rain-to-snow transition zone in southwestern Idaho. The dataset is unique not only because the site falls within this climatically sensitive zone, but also because it has instrumentation that encompasses information on the effects of both elevation and aspect on snow accumulation, and soil moisture and temperature. The dataset includes measurements of soil temperature and moisture that support studies of the interactions

25 between the atmosphere and the ground surface. The dataset spans a time period in which conditions were warmer than previous years of record, possibly representing what can be expected as regional climate warming advances. Our objective is to provide this high spatiotemporal resolution dataset to study long-term climatic trends as well as shorter-term variations at intra-event, intra-annual, and inter-annual scales.

\section{Site Description}

30 The Johnston Draw (JD) is a $1.79 \mathrm{~km}^{2}$ sub-watershed of RCEW and is located in southwestern Idaho (Figure 1). RCEW is managed by the USDA Agricultural Research Service (ARS) Northwest Watershed Research Center (NWRC) and is also a National Science Foundation Critical Zone Observatory (CZO). The elevation at JD ranges between 1497 - 1869 m, spanning the rain-to-snow transition zone where the precipitation phase at higher elevations is snow-dominated, and rain- 
Earth Syst. Sci. Data Discuss., doi:10.5194/essd-2016-44, 2016

Manuscript under review for journal Earth Syst. Sci. Data

Published: 13 September 2016

(c) Author(s) 2016. CC-BY 3.0 License.

(c) (i)

dominated at lower elevations. The annual average air temperature is $8.1{ }^{\circ} \mathrm{C}$, with precipitation averaging $611.9 \mathrm{~mm}$ annually, based on all measurement sites. Vegetation on the northern-facing slopes is characterized by Symphoricarpos, Artemisia tridentata, Populus tremuloides groves and Artemisia arbuscula with Elymus trachycaulus while southern-facing slope vegetation includes Artemisia arbuscula, Elymus trachycaulus, Cercocarpus ledifolius, and Purshia tridentata

5 [Stephenson, 1970]. The dominant soil texture on both north- and south-facing slopes is classified as sandy loam and soils are shallower ( $\sim 50 \mathrm{~cm}$ deep) on south-facing slopes compared to north-facing slopes ( $100 \mathrm{~cm}$ deep) [USDA, 2015]. The bedrock in the watershed consists mainly of granitic rock (79\%), with some basalt (3\%), and welded tuff (18\%) [Stephenson, 1970].

The dataset includes data from 11 meteorological stations and one streamflow station (Table 1). Three full meteorological

10 stations $(124,124 \mathrm{~b}$, and 125) measure an extensive suite of variables, including air temperature, relative humidity, wind speed and direction, incoming shortwave radiation, precipitation, snow depth, and soil temperature and moisture. The additional 8 meteorological stations (jdt1, jdt2, jdt3, jdt4, jdt5, jdt2b, jdt3b, and jdt4b) measure select variables for specific purposes (see Table 1 and below for details). In 2002, the ARS installed full meteorological stations at the bottom (site 125) and top (site 124) of JD, and a weir at the outflow (site 125b). During 2003 - 2005, an additional 5 meteorological stations

15 (jdt1, jdt2, jdt3, jdt4, and jdt5) were installed on the north-facing side of JD to provide measurements of temperature (Ta), humidity (RH), wind (ws and wd) and snow depth (zs) - so that along with stations 125 at the bottom and 124 at the top - a measurement site was established for every $50 \mathrm{~m}$ of elevation in the JD catchment. In 2005, a full meteorological station (site 124b) was established in an aspen grove near the top of JD to provide weather data at a wind-sheltered site. In 2010, three additional stations (jdt2b, jdt3b, and jdt4b) were installed on the south-facing side of JD, at roughly the same elevations as

$20 \mathrm{jdt} 2$, jdt3 and jdt4 on the north-facing side. At the same time, instruments to measure soil temperature $\left(\mathrm{T}_{\mathrm{g}}\right)$ and moisture $(\theta)$ were added to 8 of the 11 sites (jdt1, jdt2, jdt3, jdt4, jdt2b, jdt3b, jdt4b, and 124b) at regular depths to as deep as $100 \mathrm{~cm}$ below the ground surface. The maximum depth at each site depends on the depth to bedrock because the instruments could not be installed in bedrock or saprolite. Two soil profiles were installed at $124 \mathrm{~b}$ due to large vegetation differences within a small area: $124 \mathrm{ba}$, which is located in an aspen grove, and 124bs, which is located in mountain sagebrush. Details of the

25 sensors used to measure each parameter, as well as the sensor accuracy, operating range, and temperature dependence are provided with the data.

\section{Data Description}

\subsection{Meteorological Data}

All data presented here were checked for time inconsistencies based on the World Meteorological Organization's QA/QC 30 standards [Zahumenský, 2004]. The data were corrected and gap-filled using linear interpolation for gaps less than 3 hours or multiple linear regression for longer gaps from measurements of the same variable at surrounding sites. All observations were recorded on an hourly time step with varying start times for each station (Table 1). We have condensed the relatively 
Earth Syst. Sci. Data Discuss., doi:10.5194/essd-2016-44, 2016

Manuscript under review for journal Earth Syst. Sci. Data

Published: 13 September 2016

(c) Author(s) 2016. CC-BY 3.0 License.

(c) (i)

large amount of data into summaries to convey conditions within the watershed. For this purpose, we chose two WYs; WY2011 was a cool and wet year, and WY2014, a warm and dry year. These WYs were selected to illustrate subsequent figures and analyses because we assumed these two years represent the range and diversity of conditions during the 11-WY time period.

\section{3.1.1 Temperature and Relative Humidity}

$\mathrm{T}_{\mathrm{a}}$ and RH were measured continuously at all sites in JD from WY2004 - WY2014. Water vapor pressure ( $\left.e_{\mathrm{a}}\right)$ and dew point temperature $\left(\mathrm{T}_{\mathrm{d}}\right)$ were calculated using measured $\mathrm{T}_{\mathrm{a}}$, RH, and software tools (IPW workbench) [Frew, 1990; Marks et al., 1999b]. The IPW tools are optimized for temperatures near freezing $\left(0^{\circ} \mathrm{C}\right)$ providing greater accuracy for $\mathrm{e}_{\mathrm{a}}$ and $\mathrm{T}_{\mathrm{d}}$ as $\mathrm{T}_{\mathrm{a}}$ approaches $0{ }^{\circ} \mathrm{C}$. This accuracy is critical for the determination of precipitation phase in the rain-to-snow transition zone.

10 We define a storm as a period of time during which there are no more than 2 consecutive hours without measurable precipitation. $\mathrm{T}_{\mathrm{a}}$ during storms is $6.1{ }^{\circ} \mathrm{C}$ cooler than $\mathrm{T}_{\mathrm{a}}$ during non-storms, reflecting the dominance of winter events, whereas $\mathrm{T}_{\mathrm{d}}$ during storms is $1.5^{\circ} \mathrm{C}$ warmer than $\mathrm{T}_{\mathrm{d}}$ during non-storms. Figure 2 shows the average monthly temperatures for $T_{a}$ and $T_{d}$ for non-storms (i.) and storms (ii.) in WY2011 and WY2014. For both non-storm and storm periods, the mean $T_{a}$ and $\mathrm{T}_{\mathrm{d}}$ are also close to $0{ }^{\circ} \mathrm{C}$ for roughly 8 months out of the year (October - May), whereas during summer months (June -

15 September), these temperatures are significantly warmer than $0^{\circ} \mathrm{C}$. These mean values demonstrate the sensitivity of JD to climate warming, as changes in temperature and humidity are likely to strongly impact precipitation phase at this location.

\subsubsection{Radiation}

Incoming shortwave radiation $(280-2800 \mathrm{~nm})\left(\mathrm{S}_{\mathrm{i}}\right)$ was measured continuously at three elevations (stations $125,124 \mathrm{~b}$, and 124). Station $124 \mathrm{~S}_{\mathrm{i}}$ had to be occasionally gap-filled because $\sim 0.5 \%$ of the time series was missing. Only night-time hours

20 were missing, so gaps were replaced with zeros, matching the other two stations. The WY averages for sites 125, 124b, and 124 are $171.9,196.9$, and $193.4 \mathrm{~W} \mathrm{~m}^{-2}$, which equates to $14.9,17.0$, and $16.7 \mathrm{MJ} \mathrm{m}^{-2}$ day $^{-1}$. The diurnal cycle shifts slightly throughout the year: peak $\mathrm{S}_{\mathrm{i}}$ typically occurs $\sim 10: 00 \mathrm{am}-$ 4:00 pm (Mountain Standard Time (MST)) during summer, and $\sim 12: 00 \mathrm{pm}-2: 00 \mathrm{pm}$ (MST) during winter.

25 Longwave radiation is important in many energy balance applications, such as simulating snowmelt and evapotranspiration [Flerchinger et al., 2009], and Raleigh et al. [2016] show that longwave radiation can limit model performance. However, many measurement networks, including JD, lack instrumentation to measure this variable. Nonetheless, longwave radiation is measured within RCEW at a slightly higher elevation $(2034 \mathrm{~m})$ approximately $3 \mathrm{~km}$ to the SE of JD. According to Flerchinger et al. [2009], clear-sky longwave radiation can be accurately calculated based on $\mathrm{T}_{\mathrm{a}}$, $\mathrm{e}_{\mathrm{a}}$, and elevation using 30 methods by Ångström [1918], Prata [1996], or Dilley and O’Brien [1998], or by Marks and Dozier [1979], correcting for cloud and atmospheric effects using nearby measured values. 
Earth Syst. Sci. Data Discuss., doi:10.5194/essd-2016-44, 2016

Manuscript under review for journal Earth Syst. Sci. Data

Published: 13 September 2016

(c) Author(s) 2016. CC-BY 3.0 License.

(c) (i)

\subsubsection{Wind}

Wind speed $\left(\mathrm{w}_{\mathrm{s}}\right)$ and direction $\left(\mathrm{w}_{\mathrm{d}}\right)$ were continuously measured at seven sites. Ranging from 0.4 (the instrument threshold) to $24.2 \mathrm{~m} \mathrm{~s}^{-1}$ for all sites, $\mathrm{w}_{\mathrm{s}}$ is greatest at 124 because this site is heavily exposed to wind (Table 1). In fact, $\mathrm{w}_{\mathrm{s}}$ at the exposed 124 site is on average twice that of all other sites, ranging from 1.1 to $24.2 \mathrm{~m} \mathrm{~s}^{-1}$. During storms, wind speeds are on

5 average 1.3 times faster than during non-storms. During winter storms, $\mathrm{w}_{\mathrm{d}}$ ranges from 180 to $220^{\circ}$ (measured clockwise from north) whereas $\mathrm{w}_{\mathrm{d}}$ usually ranges between 135 and $225^{\circ}$. These values agree with the relatively consistent wind directions of 175 to $230^{\circ}$ observed in other sub-watersheds of RCEW and in the nearby DCEW [Winstral et al., 2013; Kormos et al., 2014].

\subsubsection{Precipitation}

10 The dataset includes unshielded $\left(\mathrm{ppt}_{\mathrm{u}}\right)$, shielded $\left(\mathrm{ppt}_{\mathrm{s}}\right)$, and wind-corrected $\left(\mathrm{ppt}_{\mathrm{a}}\right)$ precipitation measurements for two sites in $\mathrm{JD}(125,124)$, and shielded $\left(\mathrm{ppt}_{\mathrm{s}}\right)$ and wind-corrected $\left(\mathrm{ppt}_{\mathrm{a}}\right)$ for site $124 \mathrm{~b}$. The percentage of precipitation that is in the form of rain, snow, or a mixture of rain-and-snow was calculated using the humidity-based methods developed by Marks et al. [1999, 2013]. The precipitation data for stations 125 and 124 were wind-corrected using the dual gage correction methods developed by the ARS [Hanson et al., 2004], which incorporate a conventional under-catch correction [Hamon, 1973].

15 Because the $124 \mathrm{~b}$ site has only a single gage, the dual gage correction methods cannot be applied to this site. Instead the shielded data for 124b was wind-corrected using WMO [2008] methods. Wind exposure at the upper measurement site 124 results in roughly the same precipitation as at the lower elevation site 125 . Precipitation catch at the sheltered site $124 \mathrm{~b}$ is on average 1.2 times greater than at the wind-exposed site 124 (Table 1). Based on water balance methods, we believe that the wind-exposed values are too low and that measurements are more representative at the sheltered sites. Thus, we suggest that

20 an orographic lapse rate using only sites 125 and $124 \mathrm{~b}$ better represents the true precipitation lapse rate. We approximated precipitation for site 124b for WYs 2004 - 2007 via multiple linear regression using nearby precipitation measurement sites, which were within $1 \mathrm{~km}$ horizontally and within $100 \mathrm{~m}$ of the same elevation. Mean cumulative ppt $\mathrm{a}_{\mathrm{a}}$ for the $11 \mathrm{WYs}$ for stations $124,124 \mathrm{~b}$ and 125 was $566.3,704.7$, and $564.7 \mathrm{~mm}$, respectively (Table 1 ).

\subsection{Stream, Snow, and Soil Data}

25 3.2.1 Stream Discharge

Stream discharge was measured continuously with a stage recorder using a drop box weir at the watershed outlet [Pierson et al., 2001]. The intermittent stream draining JD typically starts flowing in early November as winter snow cover becomes continuous and ceases to flow around mid-July. Stage height was converted to stream discharge using a rating curve [Pierson and Cram, 1998] and frequent field measurements to ensure high-quality flow records [Pierson et al., 2001]. Average stream

30 discharge over the period of record is approximately $0.007 \mathrm{~m}^{3} \mathrm{~s}^{-1}$ with the largest discharge of $1.63 \mathrm{~m}^{3} \mathrm{~s}^{-1}$ on 14 February 2014 during a rain-on-snow event. Total annual runoff for each WY is shown in Figure 3. 
Earth Syst. Sci. Data Discuss., doi:10.5194/essd-2016-44, 2016

Manuscript under review for journal Earth Syst. Sci. Data

Published: 13 September 2016

(c) Author(s) 2016. CC-BY 3.0 License.

(c) (i)

\subsubsection{Snow Depths}

Snow depths were collected at all 11 sites on an hourly basis for all periods when each sensor was installed. Raw snow depths from all stations were processed in a multi-step fashion. We first defined the start and end of the snow-covered period for each WY, the peak snow depth, and a smoothing window for each sensor (usually 8 hours, but exceptions as noted below

5 are detailed in Supplemental Information). Furthermore, because the snow depth sensor is unreliable during storms due to the sonic signal reflecting from hydrometeors, these values were filtered and removed. If the gaps that this created were longer than the specified smoothing window, they were not filled. There were 127 unfilled gaps for all stations and years. If gaps were shorter than the smoothing window, then missing data were interpolated. This smoothed dataset was further quality-checked by visually comparing cumulative precipitation and changes in snow depth. If snow depth increased while

10 precipitation was zero, we extended the typical 8 hour smoothing window to 40 hours to minimize incorrectly interpreting noise as the snow depth signal. Thus, if snow depth decreased during a storm due to compaction, these data were smoothed and preserved. Mean peak snow depths can be found in Table 1. As expected, north-facing slopes and sheltered sites have deeper snowpacks that last longer throughout the snow season compared to south-facing slopes and wind-exposed sites (Figure 3), primarily due to shortwave radiation and scour differences.

15 Although this dataset does not include snow water equivalent (SWE) measurements, which complement snow depths, it appears likely that methods of converting LiDAR-derived snow depth to SWE may soon allow conversion of the 11 continuous snow depth measurements [Kirchner et al., 2014]. We expect that an improved understanding of snow melt and soil frost may build on these observed snow depth, and soil moisture and temperature measurements.

\subsubsection{Soil Moisture and Temperature}

20 Soil moisture probes were installed at 8 of the 11 sites at various depths (Table 1) in 2010 to measure $\mathrm{T}_{\mathrm{g}}$ and $\theta$. Mean WY soil temperatures reflect distinct aspect differences (Figure 4) with mean soil temperatures of $7.6^{\circ} \mathrm{C}$ on north-facing slopes and $12.5^{\circ} \mathrm{C}$ on south-facing slopes at a depth of $20 \mathrm{~cm}$.

Processing of the soil moisture data included correcting extremely dry measurements resulting from sensors with bad components. The faulty equipment was not immediately apparent because errors are only expressed when water contents are

25 very low. Thus, the reported values are accurate for all the hydrologically active periods. During the summer dry down and winter freezing events, once a value of about $0.08 \mathrm{~m}^{3} \mathrm{~m}^{-3}$ is reached, the data drop rapidly to unrealistic values, and when water contents rise due to precipitation inputs or thawing, they return to accurate values. In order to make a continuous estimate of water content and storage, we replaced the faulty values using continuous values from adjacent functional sensors. From these corrected values, we calculated the average water storage for the north-facing slopes using a soil depth

30 of $100 \mathrm{~cm}$ and for south-facing slopes using a depth of $50 \mathrm{~cm}$ (Figure 4). For both WYs, water storage on north-facing slopes is on average 1.5 times greater and lasts longer than on south-facing slopes. 
Earth Syst. Sci. Data Discuss., doi:10.5194/essd-2016-44, 2016

Manuscript under review for journal Earth Syst. Sci. Data

Published: 13 September 2016

(c) Author(s) 2016. CC-BY 3.0 License.

(c) (i)

\section{Mass Balance Analysis}

We estimated evapotranspiration using a mass balance approach based on measured precipitation and stream discharge to ensure that the measurements were reasonable when integrated at a watershed scale. We assumed that net groundwater fluxes and annual changes in storage were negligible, which is supported by soil moisture data. We approximated the annual

5 precipitation of JD by averaging the annual precipitation from $125,124 \mathrm{~b}$ and 124 . WY precipitation was estimated to be $756.9 \pm 65.6$ and $532.8 \pm 46.5 \mathrm{~mm}$ year $^{-1}$ for WY2011 and 2014, respectively. We converted annual stream discharge to specific discharge by normalizing the annual stream discharge to the watershed area. These values were estimated to be $311.4 \pm 77.8$ and $89.9 \pm 22.5 \mathrm{~mm}$ year $^{-1}$ for WY2011 and 2014, respectively. Uncertainty terms were calculated based on error propagation for sums and differences. We then used the hydrological mass balance equation to estimate

10 evapotranspiration, which was approximated to be $445.5 \pm 101.7$ and $442.9 \pm 51.7 \mathrm{~mm}^{-1}$ year $^{-1}$ for WY2011 and WY2014, respectively. These estimates agree closely with the value of $425 \mathrm{~mm}_{\text {year }}{ }^{-1}$ measured in the nearby RME catchment using eddy covariance techniques [Flerchinger et al., 2010].

\section{Data Availability}

All data presented in this paper are available from the USDA National Agricultural Library (see Enslin et al., 2016, doi 15 10.15482/USDA.ADC/12587690). The directory includes a readme file in PDF format listing the contents within each directory with a detailed data description, naming conventions, instruments used, and contact information for additional inquiries, a watershed DEM, and shapefiles of the watershed boundary and the station locations. The readme file defines the formats for the 3 precipitation files, 11 meteorological data files, 1 stream discharge file, 11 snow depth files, and 8 soil temperature and moisture files.

\section{Conclusions}

The dataset presented is the most complete and comprehensive available to date from the rain-snow transition zone. It includes 11 water years (2004 - 2014) of continuous hourly meteorological data including air and dew point temperature, relative humidity, vapor pressure, precipitation, wind speed and direction, and shortwave radiation at $50 \mathrm{~m}$ elevation intervals spanning the JD catchment. Other data include snow depth, stream discharge, and soil moisture and temperature.

25 The dataset is important for a variety of scientific questions because it: (1) captures complex atmosphere-surface-subsurface dynamics in the rain-to-snow transition zone, (2) represents hydrometeorological differences along both an elevational gradient and between aspects, and (3) provides all the necessary data required for applying a variety of models. It is our intention that this dataset will be used by scientists to improve understanding of the basin-scale interactions and responses for a mountain watershed transitioning from snow- to rain-dominated. High-resolution hydrometeorological datasets can

30 offer researchers opportunities for interdisciplinary studies at the watershed scale. For example, future studies might leverage this data to better understand how (1) changes in precipitation magnitude and temperature impact water storage and 
Earth Syst. Sci. Data Discuss., doi:10.5194/essd-2016-44, 2016

Manuscript under review for journal Earth Syst. Sci. Data

Published: 13 September 2016

(c) Author(s) 2016. CC-BY 3.0 License.

(c) (i)

movement, and the average annual snowline, (2) soil temperature and moisture respond to changes in energy and water fluxes, and (3) changes in climate impact subniveal biogeochemistry beneath transient snowpacks at the rain-snow transition.

\section{Copyright statement}

This work is in the public domain.

\section{Supplement link:}

Supplemental information (see link) includes data of the intitiation and meltout of snowpack, peak snow depth, days of snow cover, and gaps in the snow cover record.

\section{Author contribution}

C. Enslin prepared the dataset with assistance from S. Godsey, D. Marks, P. Kormos, and M. Seyfried. Datasets were 10 collected by D. Marks, M. Seyfried, T. Link, J. McNamara, and ARS staff. C. Enslin, S. Godsey, and D. Marks prepared the manuscript with contributions from all co-authors.

\section{Acknowledgments}

The data presented in this paper were collected by the USDA NWRC. We thank Adam Winstral for his contributions in expanding the JD measuring network. We also thank the NWRC and the ISU Department of Geosciences for support. The 15 collection and processing of the data presented in this paper were funded in part by the NSF-EPSCoR Program (IIA1329469), NSF-CBET (0854553), USDA-ARS CRIS Snow and Hydrologic Processes in the Intermountain West (536213610-008-00D), USDA-NRCS Water and Climate Center-Portland, Oregon (60-5362-4-003), and the NSF Reynolds Creek CZO Project (58-5832-4-004).

\section{Disclaimer}

20 Any reference to specific equipment types or manufacturers is for informational purposes and does not represent a product endorsement. ISU and USDA are equal opportunity providers.

\section{References}

Ångström, A.: A study of the radiation of the atmosphere, Smithson Misc. Collect., 65, 1-159, 1918. 
Earth Syst. Sci. Data Discuss., doi:10.5194/essd-2016-44, 2016

Manuscript under review for journal Earth Syst. Sci. Data

Published: 13 September 2016

(c) Author(s) 2016. CC-BY 3.0 License.

(c) (i)

Dilley, A. C. and O'Brien, D. M.: Estimating downward clear sky long-wave irradiance at the surface from screen temperature and precipitable water, Q. J. R. Meteorol. Soc., 124(549), 1391-1401, doi:10.1002/qj.49712454903, 1998. Enslin, C., S. Godsey, D. Marks, P. Kormos, M. Seyfried, J. McNamara and T. Link, 2016, Data set: Hydrological and ecological observations from the rain-to-snow transition zone: a dataset for the Johnston Draw catchment, Reynolds Creek

5 Experimental Watershed, Idaho, USA, Ag Data Commons, USDA Agricultural Library, http://dx.doi.org/10.15482/USDA.ADC/1258769.

Flerchinger, G. N., Xaio, W., Marks, D., Sauer, T. J. and Yu, Q.: Comparison of algorithms for incoming atmospheric longwave radiation, Water Resour. Res., 45(3), 1-13, doi:10.1029/2008WR007394, 2009.

Flerchinger, G. N., Marks, D., Reba, M. L., Yu, Q. and Seyfried, M. S.: Surface fluxes and water balance of spatially varying

10 vegetation within a small mountainous headwater catchment, Hydrol. Earth Syst. Sci., 14(6), 965-978, doi:10.5194/hess-14965-2010, 2010.

Frew, J.: The Image Processing Workbench, Ph.D Thesis, University of California, Santa Barbara, CA., 1990.

Hamon, W. R.: Computing Actual Precipitation, in WMO-IAHS Symposium on the Distribution of Precipitation in Mountainous Areas, no. 326, 159-174, 1973.

15 Hanson, C., Pierson, F. and Johnson, G.: Dual-gauge system for measuring precipitation: historical development and use, J. Hydrol. Eng., 9(5), 350 - 358, doi:10.1061/(ASCE)1084-0699(2004)9:5(3500), 2004.

Kirchner, P. B., Bales, R. C., Molotch, N. P., Flanagan, J. and Guo, Q.: LiDAR measurement of seasonal snow accumulation along an elevation gradient in the southern Sierra Nevada, California, Hydrol. Earth Syst. Sci., 18(10), 4261-4275, doi:10.5194/hess-18-4261-2014, 2014.

20 Klos, Z. P., Link, T. E. and Abatzoglou, J. T.: Extent of the rain-snow transition zone in the western U.S. under historic and projected climate, Geophys. Res. Lett., 4560-4568, doi:10.1002/2014GL060500, 2014.

Kormos, P. R., Marks, D., McNamara, J. P., Marshall, H. P., Winstral, A. and Flores, A. N.: Snow distribution, melt and surface water inputs to the soil in the mountain rain-snow transition zone, J. Hydrol., 519, 190-204, doi:10.1016/j.jhydrol.2014.06.051, 2014.

25 Lute, A., Abatzoglou, J. and Hegewisch, K.: Projected changes in snowfall extremes and interannual variability of snowfall in the western US, Water Resour. Res., 51, 960-972, doi:10.1002/2014WR016267., 2015.

Marks, D., Domingo, J., Susong, D., Link, T. and Garen, D.: A spatially distributed energy balance snowmelt model for application in mountain basins, Hydrol. Process., 13, 1935-1959, doi:10.1002/(SICI)1099-

1085(199909)13:12/13<1935::AID-HYP868>3.0.CO;2-C, 1999a.

30 Marks, D., Susong, D. and Frew, J.: Software tools for hydro climatic modeling and analysis: Image Processing Workbench, ARS USGS Version 2, in ARS Technical Bulletin NWRC-99-1, Northwest Watershed Research Center, USDA Agricultural Research Service, Boise, ID, Electronic Document, 1999b. 
Earth Syst. Sci. Data Discuss., doi:10.5194/essd-2016-44, 2016

Manuscript under review for journal Earth Syst. Sci. Data

Published: 13 September 2016

(c) Author(s) 2016. CC-BY 3.0 License.

(c) (i)

Marks, D., Winstral, A., Reba, M., Pomeroy, J. and Kumar, M.: An evaluation of methods for determining during-storm precipitation phase and the rain/snow transition elevation at the surface in a mountain basin, Adv. Water Resour., 55, 98110, doi:10.1016/j.advwatres.2012.11.012, 2013.

Morin, S., Lejeune, Y., Lesaffre, B., Panel, J.-M., Poncet, D., David, P. and Sudul, M.: A 18-yr long (1993-2011) snow and

5 meteorological dataset from a mid-altitude mountain site (Col de Porte, France, $1325 \mathrm{~m}$ alt.) for driving and evaluating snowpack models, Earth Syst. Sci. Data, 4, 13-21, doi:10.5194/essdd-5-29-2012, 2012.

Mote, P. W.: Trends in snow water equivalent in the Pacific Northwest and their climatic causes, Geophys. Res. Lett., 30(12), 1601, doi:10.1029/2003GL017258, 2003.

Mote, P. W., Hamlet, A. F., Clark, M. P. and Lettenmaier, D. P.: Declining Mountain Snowpack in Western North America,

10 Bull. Am. Meteorol. Soc., 86(1), 39-49, doi:10.1175/BAMS-86-1-39, 2005.

Nayak, A., Marks, D., Chandler, D. G. and Seyfried, M.: Long-term snow, climate, and streamflow trends at the Reynolds Creek Experimental Watershed, Owyhee Mountains, Idaho, United States, Water Resour. Res., 46(6), W06519, doi:10.1029/2008WR007525, 2010.

Newman, A. J., Clark, M. P., Sampson, K., Wood, A., Hay, L. E., Bock, A., Viger, R. J., Blodgett, D., Brekke, L., Arnold, J.

15 R., Hopson, T. and Duan, Q.: Development of a large-sample watershed-scale hydrometeorological data set for the contiguous USA: Data set characteristics and assessment of regional variability in hydrologic model performance, Hydrol. Earth Syst. Sci., 19(1), 209-223, doi:10.5194/hess-19-209-2015, 2015.

Nolin, A. W. and Daly, C.: Mapping “At Risk” Snow in the Pacific Northwest, J. Hydrometeorol., 7(5), 1164-1171, doi:10.1175/JHM543.1, 2006.

20 Pierson, F. B. and Cram, Z. K.: Reynolds Creek Experimental Watershed Runoff and Sediment Data Collection Field Manual, Rep. NWRC 98-2, Northwest Watershed Res. Center, USDA-ARS, Boise, Idaho, 30, 1998.

Pierson, F. B., Slaughter, C. W. and Cram, Z. K.: Long-term stream discharge and suspended-sediment database, Reynolds Creek Experimental Watershed, Idaho, Water Resour. Res., 37(11), 2857 - 2861, doi:10.1029/2001WR000420, 2001.

Prata, A. J.: A new long-wave formula for estimating downward clear-sky radiation at the surface, Q. J. R. Meteorol. Soc.,

25 122(533), 1127-1151, doi:10.1002/qj.49712253306, 1996.

Raleigh, M. S., Livneh, B., Lapo, K. and Lundquist, J. D.: How Does Availability of Meteorological Forcing Data Impact Physically Based Snowpack Simulations?*, J. Hydrometeorol., 17(1), 99-120, doi:10.1175/JHM-D-14-0235.1, 2016.

Stephenson, G. R.: Soil-Geology-Vegetation Inventories for Reynolds Creek Watershed. c.1970., Agric. Exp. Stn. Univ. Idaho Coll. Agric. USDA-ARS., 1970.

30 Trujillo, E. and Molotch, N.: Snowpack regimes of the Western United States, Water Resour. Res., 50, 5611-5623, doi:10.1002/2013WR014753., 2014.

USDA: Soil Survey Staff, Natural Resources Conservation Service, Web Soil Surv. [online] Available from: http://websoilsurvey.nrcs.usda.gov (Accessed 20 May 2007), 2015. 
Earth Syst. Sci. Data Discuss., doi:10.5194/essd-2016-44, 2016

Manuscript under review for journal Earth Syst. Sci. Data

Published: 13 September 2016

(c) Author(s) 2016. CC-BY 3.0 License.

(c) (i)

Wayand, N. E., Massmann, A., Butler, C., Keenan, E., Stimberis, J. and Lundquist, J. D.: A Meteorological and Snow

observational data set from Snoqualmie Pass (921 m), Washington Cascades, U.S., Univ. Washingt. Res. Work. Arch., 1-20, doi:http://dx.doi.org/10.6069/H57P8W91, 2015.

5 Winstral, A., Marks, D. and Gurney, R.: Simulating wind-affected snow accumulations at catchment to basin scales, Adv. Water Resour., 55, 64-79, doi:10.1016/j.advwatres.2012.08.011, 2013.

WMO: Part I. Measurement of Meteorological Variables, in Guide to Meteorological Instruments and Methods of Observation, vol. I \& II, pp. I.8-1 to I.9-1., 2008.

WSL Institute for Snow and Avalanche Research SLF: Meteorological and snowpack measurements from Weissfluhjoch,

10 Davos, Switzerland., , doi:10.16904/1, 2015.

Zahumenský, I.: Guidelines on quality control procedures for data from automatic weather stations, World Meteorol. Organ.

Switz., (955), 2-6, 2004. 
Earth Syst. Sci. Data Discuss., doi:10.5194/essd-2016-44, 2016

Manuscript under review for journal Earth Syst. Sci. Data

Published: 13 September 2016

(c) Author(s) 2016. CC-BY 3.0 License.

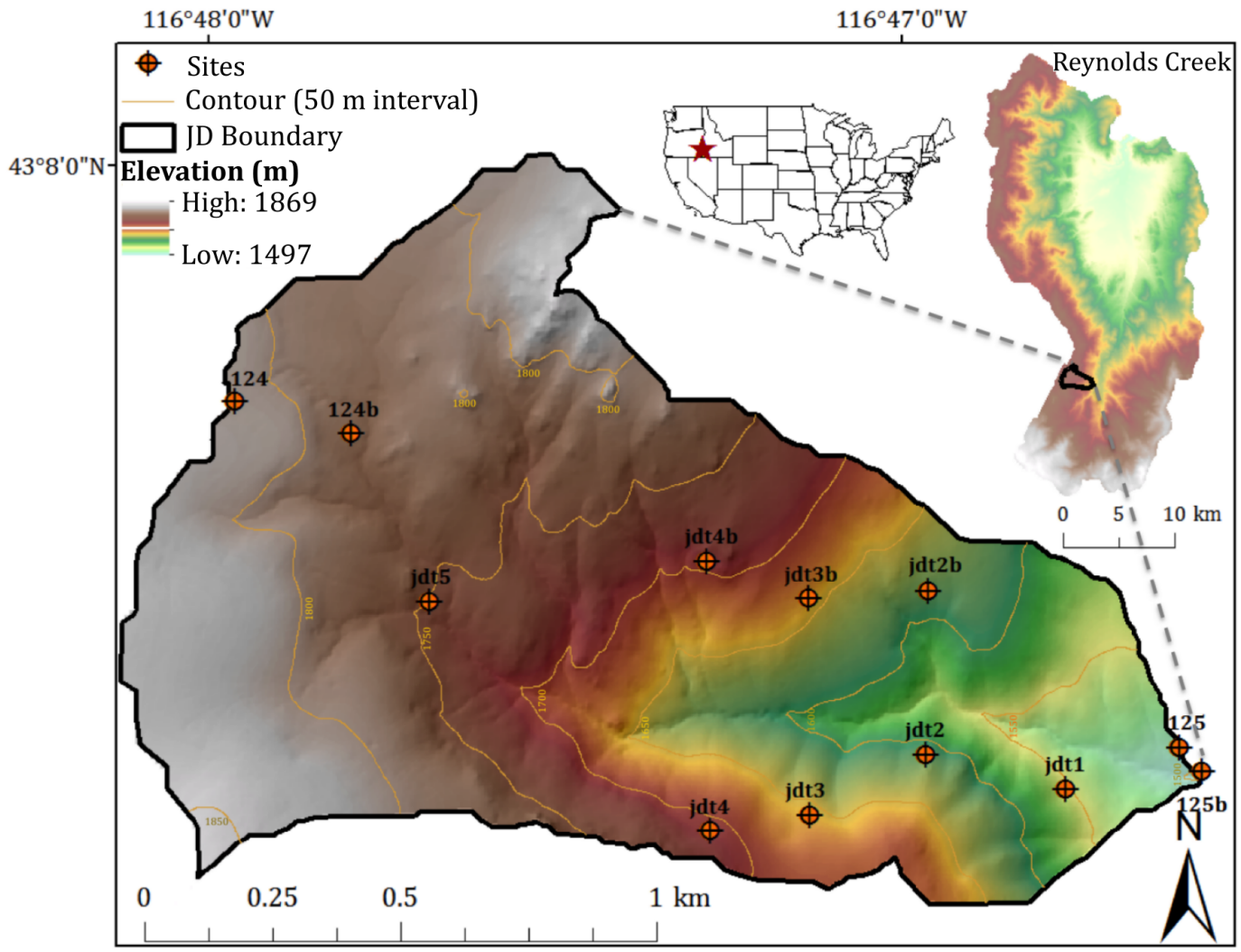

Figure 1: Johnston Draw (JD) with instrumentation location. For more information on each site, refer to Table 1 and the naming convention file attached to the data. 
Earth Syst. Sci. Data Discuss., doi:10.5194/essd-2016-44, 2016

Manuscript under review for journal Earth Syst. Sci. Data

Published: 13 September 2016

(c) Author(s) 2016. CC-BY 3.0 License.

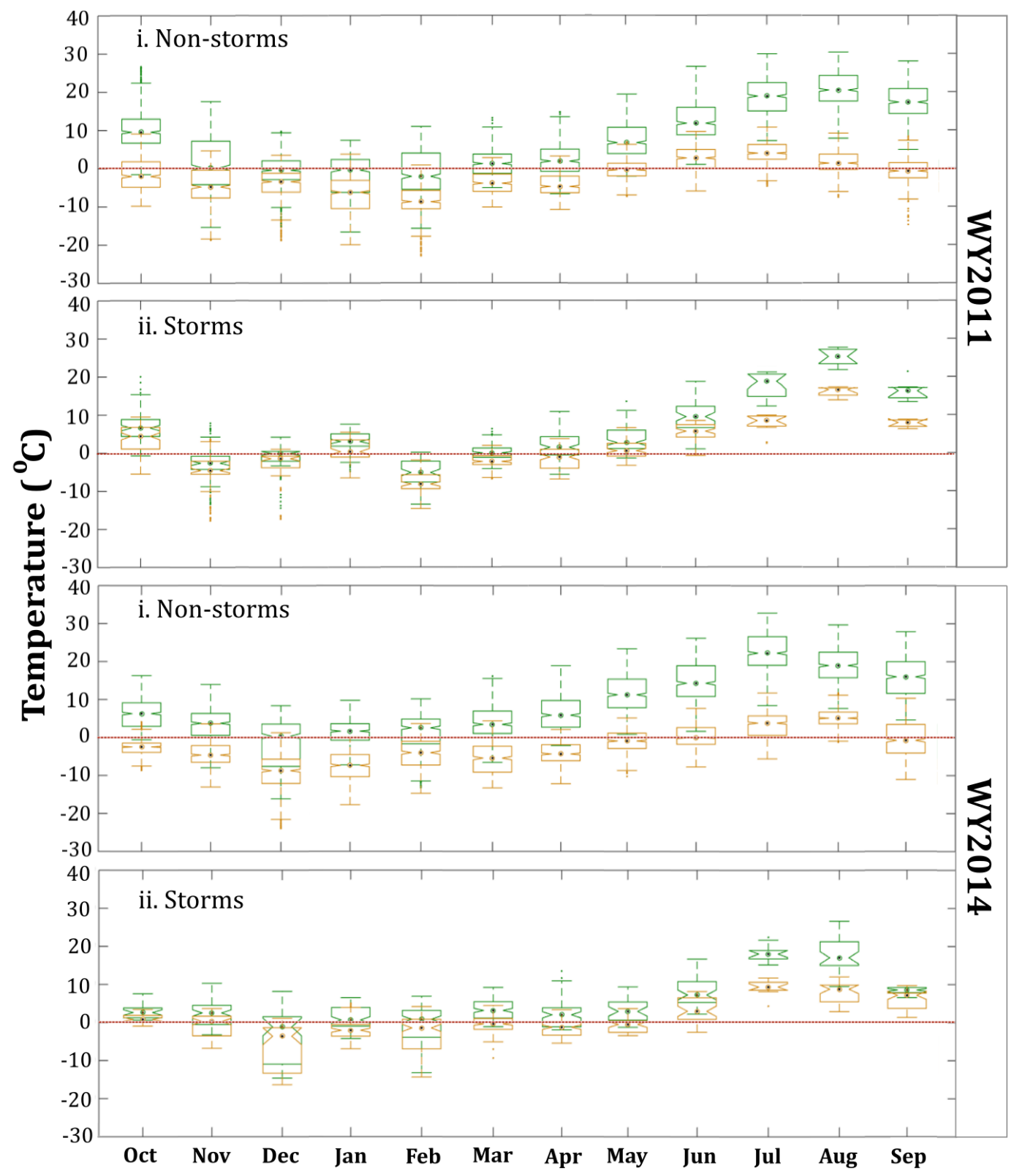

Figure 2: Monthly average $T_{a}$ (green) and $T_{d}(\tan )$ during non-storm (i) and storm (ii) periods for WY2011 and WY2014 based on data from all stations. 
Earth Syst. Sci. Data Discuss., doi:10.5194/essd-2016-44, 2016

Manuscript under review for journal Earth Syst. Sci. Data

Published: 13 September 2016

(c) Author(s) 2016. CC-BY 3.0 License.

(c) (i)

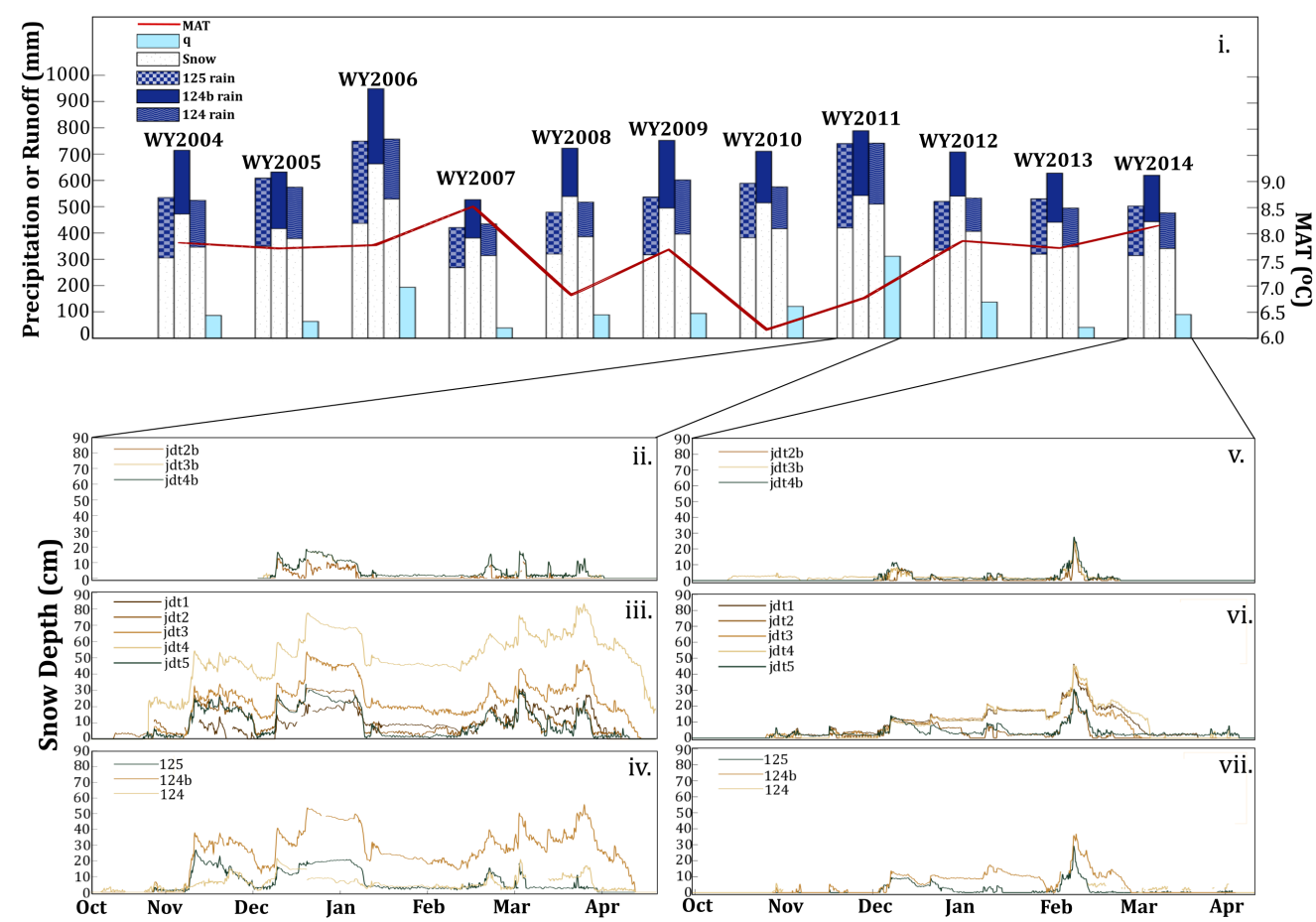

Figure 3: (i) Cumulative annual precipitation from sites 125, 124b, and 125 and cumulative runoff (q) as measured at the JD outlet and mean annual temperature (MAT) based on stations 124 and 125 which are collecting data over the entire 11 WY. (ii. - vii.) Snow depth in the JD for WY2011 (ii. - iv.) and WY2014 (v. - vii.). ii. and v. show snow depth from sites on the north-facing slopes,

5 iii. and vi. show snow depth on the south-facing slopes, and iv. and vii. show snow depth from 125, 124b, and 124. Each legend shows sites ordered from lowest to highest elevations. Snow depths increase inconsistently with increasing elevations due to wind scour from exposed sites and accumulation in sheltered areas. Gaps due to instrument failure are seen as breaks in the continuous time series line in some subplots. 
Earth Syst. Sci. Data Discuss., doi:10.5194/essd-2016-44, 2016

Manuscript under review for journal Earth Syst. Sci. Data

Published: 13 September 2016

(c) Author(s) 2016. CC-BY 3.0 License.
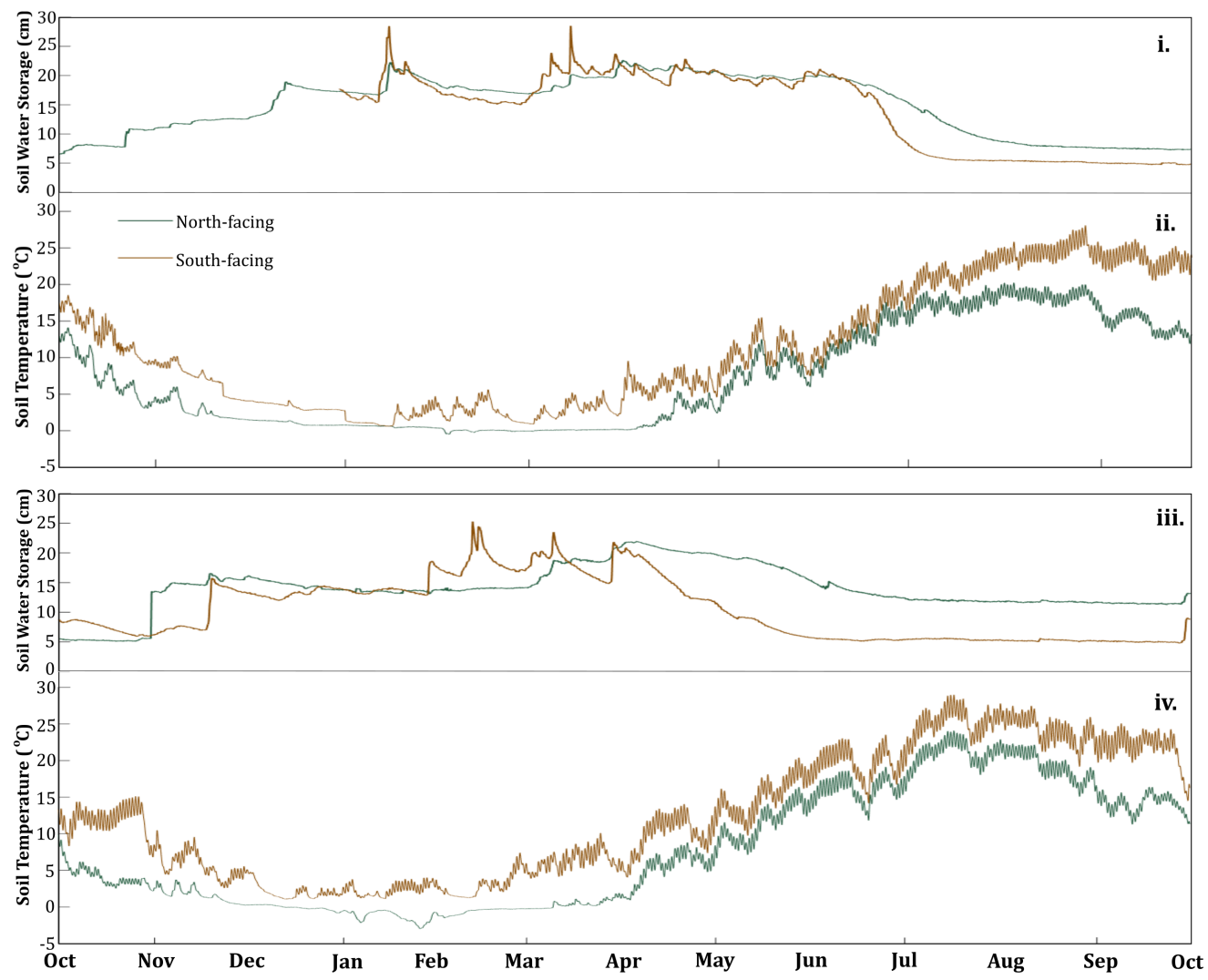

Figure 4. (i and iii) Soil water storage in both north- and south-facing slopes, up to depths of 100 and $50 \mathrm{~cm}$, respectively. The legend in (ii) applies to all subplots. Water storage for north-facing slopes was calculated based on jdt1, jdt2, jdt3, and jdt4, and water storage for south-facing slopes was calculated based on jdt2b, jdt3b, and jdt4b. During October - January of WY2011, no

5 data was recorded due to the soil moisture sensors on the south-facing slopes not being installed yet. (ii and iv) Average ground temperature $\left(T_{g}\right)$ at $20 \mathrm{~cm}$ depth on north- and south-facing slopes. Average $T_{g}$ for north-facing slopes was calculated based on jdt1, jdt2, jdt3, and jdt4, and average $T_{g}$ for south-facing slopes was calculated based on jdt2b, jdt3b, and jdt4b. 
Earth Syst. Sci. Data Discuss., doi:10.5194/essd-2016-44, 2016

Manuscript under review for journal Earth Syst. Sci. Data

Published: 13 September 2016

(c) Author(s) 2016. CC-BY 3.0 License.

\begin{tabular}{|c|c|c|c|c|c|c|c|c|c|c|c|c|c|c|c|c|c|c|c|c|c|c|c|}
\hline 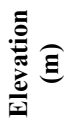 & & 薃 & 营 & 䒿 & $\overline{W Y}$ & $\begin{array}{l}\mathbf{T}_{\mathrm{a}} \\
\overline{\boldsymbol{S}}\end{array}$ & $\overline{N S}$ & $\overline{W Y}$ & $\begin{array}{l}\mathbf{T}_{\mathrm{d}} \\
\bar{S}\end{array}$ & $\overline{N S}$ & $\overline{W Y}$ & $\begin{array}{l}\mathbf{w}_{\mathrm{s}} \\
\bar{S}\end{array}$ & $\overline{N S}$ & $\overline{W Y}$ & $\begin{array}{c}\mathbf{w}_{\mathrm{d}} \\
\overline{\boldsymbol{S}}\end{array}$ & $\overline{\boldsymbol{N S}}$ & $\frac{\mathbf{p p t}_{\mathrm{a}}}{\overline{W Y}}$ & $\frac{z_{s}}{W Y}$ & $\frac{\mathrm{T}_{\mathrm{g}}}{W Y}$ & $\frac{\theta}{W Y}$ & RH & $\mathbf{S}_{\mathrm{i}}$ & $\frac{\mathrm{Q}}{\overline{W Y}}$ \\
\hline 1496 & $125 b$ & & $\begin{array}{c}1 / 10 / 03- \\
9 / 30 / 14\end{array}$ & 11 & & & & & & & & & & & & & & & & & & & 122.6 \\
\hline 1508 & 125 & $\mathrm{SE}$ & $\begin{array}{c}1 / 10 / 03- \\
9 / 30 / 14\end{array}$ & 11 & 8.4 & 3.8 & 8.7 & -1.6 & 3.8 & 8.7 & 1.8 & 2.2 & 1.8 & 195 & 208 & 193 & 566.3 & 311 & & & $*$ & 14.9 & \\
\hline 1552 & $j d t 1$ & $\mathrm{~N}$ & $\begin{array}{c}5 / 11 / 05- \\
9 / 30 / 14\end{array}$ & 9 & 8.6 & 3.3 & 9.2 & -2 & 3.3 & 9.2 & & & & & & & & 490 & 8.7 & 0.142 & $*$ & & \\
\hline 1611 & $j d t 2 b$ & $\mathrm{~S}$ & $\begin{array}{l}4 / 3 / 11- \\
9 / 30 / 14\end{array}$ & 4 & 9.4 & 3.6 & 10 & -2.3 & 3.6 & 10.0 & 1.9 & 2.5 & 1.8 & 210 & 209 & 210 & & 145 & 12.4 & 0.229 & $*$ & & \\
\hline 1613 & $j d t 2$ & $\mathrm{~N}$ & $\begin{array}{c}5 / 11 / 05- \\
9 / 30 / 14\end{array}$ & 9 & 8.2 & 2.9 & 8.9 & -2.6 & 2.9 & 8.9 & & & & & & & & 339 & 7.2 & 0.124 & $*$ & & \\
\hline 1655 & $j d t 3$ & $\mathrm{~N}$ & $\begin{array}{c}21 / 9 / 05- \\
9 / 30 / 14\end{array}$ & 9 & 8.1 & 2.8 & 8.8 & -2.6 & 2.8 & 8.8 & 2.9 & 3.1 & 2.8 & 206 & 236 & 202 & & 525 & 7.4 & 0.138 & $*$ & & \\
\hline 1659 & $j d t 3 b$ & $\mathrm{~S}$ & $\begin{array}{r}13 / 12 / 10 \\
-9 / 30 / 14\end{array}$ & 4 & 8.8 & 3.1 & 9.4 & -2.5 & 3.1 & 9.4 & 2.8 & 3.1 & 2.7 & 207 & 212 & 207 & & 195 & 12.7 & 0.155 & $*$ & & \\
\hline 1704 & $j d t 4 b$ & $\mathrm{~S}$ & $\begin{array}{l}4 / 3 / 11- \\
9 / 30 / 14\end{array}$ & 4 & 9.1 & 3 & 9.8 & -2.6 & 3 & 9.8 & 3.1 & 4.1 & 3.0 & 225 & 228 & 225 & & 234 & 12.5 & 0.145 & $*$ & & \\
\hline 1706 & $j d t 4$ & $\mathrm{~N}$ & $\begin{array}{c}2 / 11 / 05- \\
9 / 30 / 14\end{array}$ & 9 & 8.0 & 2.5 & 8.8 & -2.6 & 2.5 & 8.8 & & & & & & & & 657 & 7.3 & 0.112 & * & & \\
\hline 1757 & $j d t 5$ & $\mathrm{~N}$ & $\begin{array}{c}2 / 11 / 05- \\
9 / 30 / 14\end{array}$ & 9 & 7.3 & 1.9 & 8.0 & -2.8 & 1.9 & 8.0 & & & & & & & & 377 & 7.2 & 0.238 & * & & \\
\hline 1778 & $124 b$ & SE & $\begin{array}{r}11 / 11 / 06 \\
-9 / 30 / 14\end{array}$ & 8 & 6.7 & 1.1 & 7.4 & -2.5 & 1.1 & 7.4 & 2.0 & 2.6 & 1.9 & 226 & 239 & 224 & 704.7 & 555 & 8.3 & 0.216 & $*$ & 17.0 & \\
\hline 1804 & 124 & $\mathrm{NE}$ & $\begin{array}{c}1 / 10 / 03- \\
9 / 30 / 14\end{array}$ & 11 & 6.9 & 2 & 7.5 & -2.8 & 2 & 7.5 & 4.7 & 6.1 & 4.5 & 217 & 235 & 215 & 564.7 & 216 & & & $*$ & 16.7 & \\
\hline & & & Av & verag & 8.1 & 2.7 & 8.8 & -2.4 & 2.7 & 8.8 & 2.7 & 3.4 & 2.6 & 212 & 224 & 211 & 611.9 & 368 & 9.3 & 0.2 & & 16.2 & 122.6 \\
\hline
\end{tabular}

Table 1. Stations within Johnston Draw watershed, their elevations, and available parameters at each station. Although data presented in this dataset are limited to the end of WY2014, data from all stations continues further than WY2014 as all stations are currently maintained. The characters "rc.tg.dc.jd-"precede the station name, however for simplicity, the names of stations all 5 figures and in the text for simplicity are shown below. Because $\mathbf{T}_{\mathrm{d}}$ was calculated based on $\mathrm{RH}$ (see text for details), $\mathrm{RH}$ is not summarized here. The asterisks indicate which stations include this measurement. $T_{a}-$ air temperature $\left({ }^{\circ} \mathrm{C}\right), \mathrm{RH}-$ relative humidity $(0.0-1.0), w_{s}, w_{d}-$ wind speed $\left(\mathrm{ms}^{-1}\right)$, wind direction $\left(0-359^{\circ}, 0=\right.$ north; $180=$ south $), S_{i}-$ incoming solar radiation $\left(\mathrm{Wm}^{-2}\right.$ - here reported in $\left.\mathrm{MJ} \mathrm{m}^{-2} \mathbf{d a y}^{-1}\right), \mathbf{p p t}_{\mathrm{a}}$ - wind-corrected precipitation, respectively $(\mathrm{mm}), \mathrm{z}_{\mathrm{s}}-$ snow depth $(\mathrm{mm}), \mathrm{T}_{\mathrm{g}}-\mathrm{soil}$ temperature $\left({ }^{\circ} \mathrm{C}\right), \boldsymbol{\theta}$ - soil water or moisture $\left(\mathrm{m}^{3} \mathrm{~m}^{-3}\right), \mathrm{Q}$ - streamflow $(\mathrm{m} 3 \mathrm{~s}-1), \overline{\mathrm{WY}}=$ mean WY value, $\overline{\mathrm{S}}=$ mean storm value and

$10 \overline{\mathrm{NS}}=$ mean non-storm value. $\overline{\mathrm{WY}}$ for $\mathrm{T}_{\mathrm{g}}$ and $\boldsymbol{\theta}$ at $124 \mathrm{~b}$ were calculated based on the two subsurface measurement locations at this site (see text for details). 